Klassikern:

\title{
MUSEETS PLATS I SAMTIDENS BILDNING OCH KULTUR
}

\author{
Stanislas S Adotevi
}

Under ICOM's betydelsefulla nionde generalkonferens $i$ Grenoble 1971 framträdde Stanislas Adotevi frän dàvarande Dahomey (nu Benin) i Västafrika. Han var en ledande kulturpersonlighet i det frankofona Afrika, ledare för Dahomeys Institut de Recherche Appliquée, under vilket museerna sorterade. Hans svidande kritik av den europeiska museivärlden väckte stort uppseende i Grenoble och har kommit att betraktas som en viktig inspiration för den nya museologi och för ekomuseirörelsen tog form vid den här tidpunkten. Så åberopas han med utdrag ur talet $i$ Gjestrum-Maures Økomuseumsboka (1988) och med talets inledande avsnitt i André Desvallées Vagues, 1 (1992). Hela texten finns publicerad $i$ Le rôle éducatif et culturel du musée. Le musée au service des hommes aujourd'hui et demain, Actes de la 9e Conférence générale de l'ICOM. (Paris 1972). Den följande översättningen är gjord efter utdraget $i$ Vagues. Dock är slutorden hämtade ur originaltexten.

Den insikt vi nått vid detta sekels slut, när vi sett resultaten av museernas verksamhet under de senaste seklen, när vi känner den (innestående) fordran som utvecklingsländerna har, när vi lärt Afrikas historia både gårdagens och särskilt morgondagens - allt pekar på att museerna måste avskaffas. Jag kan naturligtvis bara ta till orda som utomstående iakttagare. Men jag har sett museer i Afrika, har stått inför dem i Europa och på många platser i tredje världen. Jag tror att bokslutet är uppenbart överallt. Museet som är kvintessensen av den humanistiska bildningstraditionen har ingenting att göra med det mänskliga livets grundstoff. Utan tvivel kommer jag att anklagas för att hänga upp mej på detaljer, att bara bry mig om det iögonenfallande, att bortse från mera grundläggande sanningar, att förväxla resultatet med projektets syfte. Utan tvivel! Men låt oss se närmare på argumenten (för museer) som är av åtminstone tre slag:

1. Om museet på det personliga planet är en oersättlig källa till fördjupad insikt, har den ambition som, exempelvis i Frankrike, skapade museet verkligen på det kollektiva planet givit det franska folket ökade insikter?

2. Att först känna sitt land är det den enda hållbara grunden för den nutid som är 
vår plikt och uppgift att forma? Och är det verkligen ett ideal att erbjuda de unga nationer som idag skall skapa en egen framtid?

3. Om nu museerna är bristfälliga, måste vi ändå inte betrakta dem som en möjlig direkt kontakt med verkligheten, som skulle kunna göra bättre utställningar, utveckla sin förmedlingsverksamhet, sina trycksaker, sin information?

Alla dessa frågor kan lätt besvaras. Utan uppdrag att tala för alla dem som blir uttråkade i museer kan man ändå inte med utgångspunkt från vad som sker i Afrika enligt talrika artiklar skrivna av ansedda specialister - åtminstone konstatera att det föreligger ett problem? Vidare finns vältaliga rubriker - den på vår konferens bl a! - Museet till människans tjänst idag och $i$ morgon. Så finns tekniska studier som Duncan Camerons Problems in the language of museum interpretation. Andra slutligen som ligger närmare mitt tema: Museerna - vad kan de tillföra oss? I alla dessa fall söker man förgäves bortom den sinnrika begreppsapparaten och de tekniska finesserna något som kan dölja osäkerheten hos några, oron hos andra. Man påstår förgäves bestämt (som man gör $\mathrm{i}$ inledningen till den sammanfattning som presenterades efter musei-kollokviet i Unesco-huset 1969) att museet tack vare de väldiga intellektuella, moraliska och materiella resurser som det förfogar över, och med den långa utveckling det genomgått, utgör en av de mest påtagliga kulturinstitutionerna $i$ den samtida världen, men lyckas knappast få oss att glömma att museet är en motsvarighet till kyrkogården, där man vördar dem som gått före och brutit vägen. Eller snarare: det är ramen till den spegel där man ser föregångarna, förfäder183 na, slita ut sig för att bygga grunden för de nu levandes existens. Det är slutligen den osannolika plats dit folken utan historia kallas för att lära sig historia, dvs mänsklighetens historia, mitt bland statyerna, danserna, mellan två rytmer, med hjälp av riter. Med detta förhållningssätt kan allt hända. Och allt händer faktiskt. Dogon-skulpturer, men bara en och av metall! Undervisning ... ?

Jag talar ännu inte om kulturarv. Jag talar om fantasibilder och jag vågar säga därför att det måste sägas utifrån en bestämd bild av Afrika - att statyetterna, riterna, danserna, alla dessa företeelser som man presenterar för att ange vår egenart, inte återfinns i något museum; ännu mindre i något museum på afrikansk jord. De här sakerna - danserna, statyetterna, kulturarvet, kan man ännu möta i Afrika, men långt från de centra som förser turisterna och alla dem som lärt sig genom kamerabilder. Danserna, riterna, maskerna, vardagsverkligheten levs fullt verkligt $\mathrm{i}$ offentlighetens ljus, i varje gest, individuell eller gemensam, genom män och kvinnor av kött och blod och inte bara på ett teoretiskt eller drömlikt sätt i afrikanisternas lärda arbeten eller i salar för temporära eller permanenta utställningar. För att vara ännu mer direkt är det nödvändigt att här ta ställning, här som annorstädes mot alla dem som av tredje världen och särskilt av Afrika, vill göra ett museum. Det handlar till slut på ett mer generellt sätt om att veta att en ny civilisation åtminstone från 1968 håller på att växa fram utom räckhåll för dem som bemödar sig om att av museerna göra en institution och av människor en handelsvara. 
184 Men vad är då ett museum och hur kan det genom en i sann mening humanistisk verksamhet medverka till att skapa en ansvarskännande kultur? Hittills har museet hämtat sitt berättigande ur en obestämd önskan, som man anstränger sig att benämna det mänskliga kulturarvets bevarande. Det finns mycket seriösa personer som talat därom i sina föreläsningar och särskilt i romaner eller böcker allteftersom industrialismen avslöjat sina anspråk på att erbjuda ojämförliga möjligheter. Men kultur är också - åtminstone efter Descartes och särskilt Kant och Hegel - en tro på förnuftet. Dock kan industrialismen - skapad av samma förnuft - inte tillväxa annat än genom att förgöra samma förnuft som givit upphov till dess existens. Fångad i motsägelsefällan har den vuxne europén (förnuftig och civiliserad resonör i den självpåtagna rollen som kulturspridare) $\mathrm{i}$ avsikt att rättfärdiga sin verkliga (eller låtsade) förkärlek för det förflutna och sin verkliga (och ej låtsade) omsorg om framsteget, uppfunnit denna geniala institution (museet) där alla snarkar. Och Afrika har skyndat sig att introducera den samtidigt som kontinenten garanterat slavhandeln och all annan exploatering.

Museet, en skapelse från den förindustriella tiden, som överlevt tack vare författares nycker och snobbars komplex, är teoretiskt och praktiskt förbundet med en värld (europeisk), med en klass (det kultiverade borgerskapet) och med en bestämd kultursyn (våra förfäder gallerna och deras kusiner, alla blonda långskallar med blå ögon). Denna värld håller otvivelaktigt på att försvinna samtidigt likviderad av industrialismens inre förstelning och den senaste historiens förkastelsedom, men museet fortsätter trots detta att förbli platsen där en samhällsklass dammiga (otidsenliga) passioner på ett magiskt sätt koncentereras, en samhällsklass som ännu tror att dess makt kan vidmakthållas. Att museerna har stor publik förändrar ingenting. Faktum är att - eftersom världen ser ut som den gör åtminstone sedan tio år en ny social praktik lika litet bekymrad om människan själv som den gamla humanistiska maskeraden - håller på att formeras av de svarta i maskopi med alla dem som vid de fina husens köksingångar redan drömmer om minnen och nostalgi. Vidare - frågan är inte vad småbönderna från Cantal eller de unga negrerna från bushen kommer att göra i museerna utan vad de kommer att se. Vad söker de efter? Och vilka samband mellan det de vill se eller tror sig se och textens eller talets faktiska värld? Med andra ord - vad kan ett museibesök ge tillbaka till det samhälle som erbjuder besöket? Det är följaktligen nödvändigt att gå till grunden med den museala verklighetens teori och förstå varför museet har förskansat sig i sin myt och därför är hotat av inre förvittring.

Att det på flera håll i världen finns levande, progressiva museer ändrar ingenting i sak. Att museer nu framträder som brutit med den traditionella museologin, bevisar tvärtom att institutionen som sådan är dömd, dömd just därför att den förnekas av majoriteten, dvs av den nya generationen. [...]

En ny museologisk praktik måste bereda marken för en i verklig mening ansvarstagande kultur. Den kan inte göra det utan att angripa problemen vid roten. Ty, säger oss Marx, människans rötter är människan själv. Museologin måste gå till rötterna annars saknar den berättigande. 